\title{
Dynamics of Energy Consumption Patterns in Turkey: Its Drivers and Consequences
}

\author{
Gülden Bölük ${ }^{* 1}$, A.Ali Koç² \\ ${ }^{1}$ Akdeniz Univesity, Department of Economics, Antalya, Turkey \\ ${ }^{2}$ Akdeniz Univesity, Department of Economics, Antalya, Turkey \\ * Tel: 90242 3106407, Fax: +90 24222744 541, E-mail:guldenboluk@akdeniz.edu.tr
}

\begin{abstract}
Turkey has a characteristics with very young population, high annual population growth rate, rapid urbanization and relatively high economic growth rate. Turkey's population has reached about 73 million in 2010 The country has faced with growing demand for energy during last two decades and primary energy demand is projected to reach 220 mtoe in $2020 \mathrm{w}$ hich means 150 percent increase from current level. But primary energy supply met about 28 percent of energy demand in 2009. Increasing import dependency highlights the energy security problem for the country and also poses important burden on economy such as foreign current deficit. Total energy import increased nearly six folds for last 15 years with 12 percent annual average growth rate. The share of energy in total import has exceeded 20 percent in recent years. Increasing GHG emissions is another issue which has substantially increased during last two decade, particularly emitted from energy production. Therefore, energy dependency and GHG emission issues entails investment in renewable energy sources such as wind, biomass, hydro and solar to both reducing energy dependency and emission. In addition, ensuring greater energy efficiency will contribute energy security since current level of efficiency is rather low.
\end{abstract}

Keywords: Turkey's energy consumption dynamics, drivers of energy demand, impacts of energy policies.

\section{Introduction}

Turkey has been rapidly growing country for decades. The gross national product of country has grown at an average annual rate of 5 percent since 1983 . Turkey's energy demand has also risen rapidly as a result of economic growth and development. Turkey has an economy challenging by a growing demand for energy while its self sufficiency rate in primary energy sources are very low. Total primary energy production met about 28 percent of the total primary energy demand in 2009.

Turkey is heavily dependent on expensive energy imports which impose significant burden on the economy. As a result of increasing energy consumption, air pollution has been causing severe environmental issues in the country. Furthermore, to meet criteria of Kyoto Protocol, consumption pattern needs to be modified. As a candidate country, Turkey will have to adopt the bio-energy and bio-fuel directives of the EU in case of membership. In this regard, promoting renewable energy resources seem to be one of the effective energy policies in Turkey which also entails substantial investments.

The aim of this article is to analyze the dynamics of the energy consumption patterns in Turkey and evaluate the impacts of energy demand patterns change both on energy sector and whole economy. Furthermore, this paper aims to contribute the national energy sources management and policy decision by analyzing the energy demand patterns change and its macroeconomic consequences. The paper is organized as follows. In the second section, macroeconomic drivers of energy demand in the economic development process and national energy policy are presented. In the third section energy sector and energy consumption structure are analyzed. In the fourth section implications for energy consumption patterns change is evaluated. Final section concludes important results. 


\section{Energy Policies in Turkey and Macroeconomic Drivers for Energy Demand}

Turkey is situated at the meeting point of the three continents (Asia, Europe and Africa) and is adjacent to regions which pose over $70 \%$ of the world's proven oil and natural gas reserves. Moreover Turkey sits on major international waterways. Therefore Turkey is an important transit state for world energy resources [1]. Turkey's size $779,452 \mathrm{~km}^{2}$ and Turkey's population was about 73 million in 2010. Moreover fast migration from rural regions to industrial and/or tourism regions has continued and fast growing urbanization is leading more energy consumption. Turkey is rapidly growing economy, and over the past decade it's Gross Domestic Product (GDP) has increased an exceptional rate compared to other OECD countries. Turkey is 17 th largest economy expanded on average by $4.7 \%$ a year [2].

Since 1980 (in liberal period), public investments including electricity investments has been gradually cut down to reduce the public share in the economy. Moreover, the Turkish government initiated some legal regulations to attract the private investors to the economy [3]. By the end of the 1990s, it was understood that quasi-privatization policies were not going on to be feasible given the rapidly deteriorating fiscal situation. Thus, Turkey adopted a radically different framework for the design of the energy markets. In 2003, Electricity Market Law (EML, No:4628) came into force [4]. The EML was designed to establish a competitive electricity market, to promote private participation and improve the efficiency in electricity supply [3]. In parallel with the electricity market reform, some other reforms were also initiated in other segments of market. In 2001, Natural Gas Market Law (NGML, No: 4646) also came into force to achieve similar goals in natural gas industry. The new regime established the Energy Market Regulatory Authority (EMRA). Also, Petroleum Market Law (PML, No:5015) and Liquefied Petroleum Gas Market Law (LPGM, No:5307) was enacted in 2003 and 2005 respectively. EMRA has responsibility for regulation of these markets as well [4].

Table 1: Population, Economy and Energy in Turkey, 1973-2020.

\begin{tabular}{cccccc}
\hline Year & $\begin{array}{c}\text { Population } \\
(1000)^{*}\end{array}$ & $\begin{array}{c}\text { Population } \\
\text { Increase, }(\% \text { o) }\end{array}$ & $\begin{array}{c}\text { GDP per } \\
\text { capita, }\left(\$^{* *}\right)\end{array}$ & $\begin{array}{c}\text { GDP, at current } \\
\text { prices, }(\text { billon } \\
\text { USD) }\end{array}$ & $\begin{array}{c}\text { Total Energy } \\
\text { Consumption, } \\
\text { (Mtoe) }\end{array}$ \\
\hline 1973 & 38,073 & 20.7 & $2,369.00$ & 90.2 & 20.04 \\
1990 & 55,120 & 17.0 & $3,859.52$ & 202.38 & 40.55 \\
1995 & 59,756 & 15.4 & $6,693.43$ & 223.74 & 63.21 \\
2000 & 64,259 & 13.8 & $8,149.60$ & 265.18 & 82.2 \\
2005 & 67,903 & 13,0 & $11,005.80$ & 482.78 & 92.5 \\
2010 & 72,698 & 11.0 & $15,392.16$ & 729.05 & 97.31 \\
2020 & 80,257 & 8.8 & $19,748.55$ & $1,344.29$ & 220.0 \\
\hline
\end{tabular}

* Mid-year population data; ** IMF, International USD PPP equivalent Source: $[5,6,7,2,8]$.

Turkey's GDP is expected to grow at a rate $5 \%$ in 2012 and $5.5 \%$ in 2013 [9]. Turkey is also expected to fastest medium-long term growth in energy demand among the IEA counties. The total energy consumption is expected to reach 220 Mtoe by the year 2020. But, Turkey's energy consumption per capita is still relatively low compared to developed countries [2]. As mentioned before, Turkey is a candidate country to EU. Therefore all candidate countries need to harmonize with the European Union energy policies. Moreover all candidate countries should have adequate legislation and well functioning institutions. In this regard, Turkey adopted a strategy which consists of a privatization and integration into European and global economy. EU energy policies essentially include the improvement of competiveness, security 
of energy supply and protection of environment [10]. In this context, some efforts for sustainable energy, energy efficiency and environmental issues have been observed in Turkey [11]. As a matter of fact, the Renewable Energy Law (REL, No:6094) was enacted by the Turkish Grand National Assembly in December 28, 2010.

\section{Dynamics of Energy Patters}

Energy consumption of Turkey has grown substantially since the beginning of the 1970s. The quantity of consumption almost quintuplicated between 1973 and 2010 from 20.4 to 97.31 millions tons of oil equivalent (Mtoe). Turkey's energy consumption is rapidly growing, but it's domestic primary energy sources (especially oil and natural gas) are relatively low. According to the Ministry of Foreign Affairs [7], primary energy demand is projected to reach 220 million toe in 2020, revealing 150 percent increase as compared to the current figure.

Table 2: Production, Supply and Consumption of Energy Sources in Turkey, thousand TEP,2008.

\begin{tabular}{cccc}
\hline Energy & Domestic Production & Primary Energy Supply & $\begin{array}{c}\text { Total Final Energy } \\
\text { Consumption }\end{array}$ \\
\hline Hard Coal & 1204 & 14179 & 7010 \\
Lignite & 15205 & 15003 & 4138 \\
Oil & 2268 & 31784 & 28732 \\
Natural Gas & 931 & 33807 & 13957 \\
Hydroelectric & 2861 & 2861 & 0 \\
Wood & 3679 & 3679 & 3669 \\
Biofuels & 66 & 66 & 66 \\
TOTAL & 29257 & 106338 & 79559 \\
\hline
\end{tabular}

Source: [13].

According to the MENR statistics (2008), petroleum products, natural gas and coal consist of the bulk of the primary energy consumption in Turkey. Although the consumption of oil has been increasing for the several decades, because of the natural gas, this rate was started to decrease. Roughly 90 percent of Turkey's oil supply is being imported. But oil is still the dominant energy source in Turkey. In the past four decades oil's shares were $42.3 \%, 45.5 \%$, $41.1 \%$ and $36.1 \%$ for $1970,1990,2000$ and 2008 respectively. Turkey oil consumption was 28,732 thousand TEP in 2008 [13]. Turkey's oil production in 2008 met only 7.9 of total in consumption [5]. The oil deficit between production and final consumption was met by imported oil from Saudi Arabia, Libya, Iran, Iraq, Russia, Syria and Algeria.

Turkey is a transforming country, so energy usage has shifted towards to manufacture sector and cycle and energy sector. While the manufacture sector share in total energy consumption was $24.5 \%$ in 1970 , this share nearly doubled in 2006. Moreover share of the cycle and energy sector increased more than two folds from 1970 to 2006. The shares of cycle and energy sector were $12 \%$ and $28.6 \%$ for 1970 and 2006 respectively. Shares in total energy demand for households, transportation, agriculture and out of energy were $30.7 \%, 19.3 \%$, $4.6 \%$ and $5.4 \%$ respectively. In the power sector it is expected that oil-fired power plants will continue to be replaced by other forms of power plant technologies [2].

Natural gas consumption has risen substantially in recent years in Turkey. The shares for natural gas in energy consumption for 1970, 1980, 1990 and 2008 were $0 \%, 5.9 \%, 17.5 \%$ and $31.6 \%$ respectively. Natural gas has been particularly important in the power sector which has risen to tenfold from 1990 to 2008. Gas usage is expected to continue to increase rapidly in all sectors for medium and long term (61 bcm in 2020). Turkish natural gas is anticipated to 
increase rapidly over the next years with the most important consumers expected to be natural gas fired electric power plants and industrial users. Total natural gas production only met 6.7 $\%$ of gas consumption and the rest of the natural gas consumption (93.3\%) was imported. Natural gas has been imported mainly from Russia, Algeria, Iran and Nigeria. Turkey produces only a small amount of natural gas and therefore natural gas imports have increased rapidly [14]. Coal has been a major fuel source in energy consumption in Turkey after the oil and natural gas since 1970s. The share of coal (hard coal plus lignite) in consumption was $15.4 \%$ in 1970 and declined to $14.4 \%$ in 2008 . Around 87 percent of domestic lignite is used for generating electricity in 2008. Power generation, industry (including coke ovens and blast furnaces) household usage accounted 46, 44 and 9 percent respectively in hard coal plus lignite consumption in 2007 [2].

There has been also rapid increase in electricity consumption. It has grown $9-10 \%$ per year except for recent economic crises. Electricity demand reached 194,079.1 $\mathrm{Gwh}^{1}$ in 2009 and increased tenfold over the last 25 years [15]. Although significant increase realized in electricity consumption per capita in 2009 (2699 $\mathrm{kwh} /$ year), it is still under the EU average $(6500 \mathrm{kwh} /$ year $)$ and developed countries average $(8900 \mathrm{kwh} /$ year $)$ and just above the world average (2500 kwh/year) [16]. Electricity consumption increase is expected to continue over the next 15 years [17]. Besides natural gas, another fast growing source for electricity is coal. From 2000-2009, gas fired generation grew by 48 Twh, accounting for $72 \%$ of total power generating. Coal fired grew by $17 \mathrm{Twh}$, accounting for $25 \%$ of demand [2]. Demand projections up to 2018 indicate that annual average increase in demand will be $7 \%$ and $6.3 \%$ in high and low demand scenarios respectively [18].

\section{Implications of Energy Consumption Pattern}

As mentioned before, demand for energy has been rapidly increasing [19]. But Turkey's self sufficiency rate in primary energy source is very low. Total primary energy production met about 28 percent of total primary energy demand in 2009 and Turkey has no significant oil and natural gas reserves. So the first inevitable result of energy consumption in Turkey is energy security issue. Turkey is highly dependent on i mported primary energy sources. Energy import by the sectoral break down is presented in Table (3).

Table 3: Energy Import by ISIC Rev 3 of Turkey, million \$, 1996-2010

\begin{tabular}{|c|c|c|c|c|c|c|c|}
\hline Energy/Year & 1996 & 2000 & 2006 & 2007 & 2008 & 2009 & 2010 \\
\hline $\begin{array}{l}\text { Hard Coal, cooking } \\
\text { coal and briquette }\end{array}$ & 623,5 & 676,3 & 2054,5 & 2666,5 & 3411,7 & 3113,4 & 2518,5 \\
\hline $\begin{array}{l}\text { Petrol and petroleum } \\
\text { based products }\end{array}$ & 3998,3 & 5642,7 & 16608,3 & 19339,4 & 27034,4 & 15171,8 & 16921,2 \\
\hline $\begin{array}{l}\text { Natural gas and } \\
\text { manufactured gas }\end{array}$ & 1280,4 & 3078,6 & 10177,7 & 11856,5 & 17819,3 & 11602,7 & 11185,2 \\
\hline Total energy import & 5913,9 & 9529,3 & 28858,7 & 33882,8 & 48280,9 & 29905,1 & 30640,0 \\
\hline $\begin{array}{l}\text { Energy import share in } \\
\text { total import. }\end{array}$ & 13,5 & 17,5 & 20,7 & 19,9 & 23,9 & 21,2 & 20,7 \\
\hline
\end{tabular}

Source: [5].

\footnotetext{
${ }^{1}$ Gross demand is obtained by Gross Generation + import-export (15).
} 
The highest dependency rate with 93.3 percent is in natural gas. Dependency rate for oil and hard coal are $92 \%$ and $91 \%$ respectively. It is projected that the production will decrease and meet the $23 \%$ of total energy demand in 2020 which was 28 percent in 2009 . This energy import dependency poses important burden on economy. The oil and natural gas import is expected to substantially increase over the next decade. The natural gas share in total import is expected to be $33 \%$ in 2020 [2, 20]. Turkey's total energy import has increased nearly six folds for last 15 years and reached to 48281 million US Dollar in 2008 and 30640 million US Dollar in 2010. Energy import bill has nearly grown with annual average 12 percent except 2009. Economic crises in 2008 let to decrease in energy import in 2009 but this slowdown reversed again in 2010. The energy import share in total energy import also increased during last 15 years and constitutes about $20 \%$ of the country total import. Because of the high import dependency rate, the government has developed an energy policy aimed at diversifying energy sources and suppliers and attracting private capital in Turkey [21]. Hence domestic energy sources of Turkey become strategically important. Although Turkey has no large oil and natural gas reserves, it has promising significant energy sources like coal (mainly in lignite), hydro and geothermal [10]. Turkey has also the great remaining potential for hydro. It is stated that Turkey's hydro electric potential can meet 33-46\% of electricity demand in 2020. Based on the electricity supply and demand projections, it has been targeted that the share of the nuclear power plants in electricity production will be $5 \%$ by the 2020 . For this purpose, Construction and Operation of Nuclear Power Plants and Law on Sale of Energy (No:5710) came into force in 2007. An intergovernmental agreement was signed between Turkey and Russia for the construction a nuclear power plant in Mersin-Akkuyu [12]. In the context of the energy diversification issue in Turkey, alternative energy sources such as biofuels became an important focus in recent years. Furthermore, as a candidate country, Turkey will have to adopt the bio-energy and bio-fuels directives of EU in case of membership. Turkey has potential for ethanol based biofuels [22]. European Commission introduced a legislative framework to promote the achievement of $20 \%$ target for renewable energy in 2020 [23]. According to the [12], the renewable energy share in electricity energy is planned to be $30 \%$ in 2023 in Turkey.

Table 4: GHG by Sectors in Turkey, 1990-2008, million tones $\mathrm{CO}_{2}$ equivalent

\begin{tabular}{lccccc}
\hline Sectors & 1990 & 1995 & 2000 & 2005 & 2008 \\
\hline Energy & 132.13 & 160.79 & 212.55 & 241.75 & 277.71 \\
Industrial Process & 15.44 & 24.21 & 24.37 & 28.75 & 29.83 \\
Agricultural activities & 29.78 & 28.68 & 27.37 & 25.84 & 25.04 \\
Waste & 9.68 & 23.83 & 32.72 & 33.52 & 33.92 \\
Increase to 1990 (\%) & - & 26.99 & 58.80 & 76.37 & 95.96 \\
\hline
\end{tabular}

Source: [5].

In Turkey, the highest growth of $\mathrm{CO}_{2}$ emission between 1990 and 2008 was observed in energy industries with $114 \%$ in 2008 . It is followed by manufacturing industries with $79 \%$. Approximately $91 \%$ of total $\mathrm{CO}_{2}$ emission has been emitted from energy sector and the rest portion, which is $\% 9$, was originated from industrial processes in 2008 . However, $59 \%$ of $\mathrm{CH}_{4}$ emission is originated from waste disposal and 31\% from agricultural activities while $72 \%$ of $\mathrm{N}_{2} \mathrm{O}$ emission is from agricultural activities. In terms of fuel combustion, $36 \%$ of total $\mathrm{CO}_{2}$ emissions is originated from energy industries while $19 \%$ from manufacturing industries, $16 \%$ from transport and $21 \%$ from other sectors in 2008. Energy related $\mathrm{CO}_{2}$ emissions have more than doubled since 1990 and it will most likely to continue to increase fast over the medium and long term because of the increasing energy demand [5]. 
Turkey is a Party to United Nations Framework Convention on Climate Change (UNFCCC) and a Party to Kyoto Protocol in 2009. However, as developing economy with low emission per capita, Turkey has preferred not to determine quantitative overall target to limit emissions. Although Turkey has no legal compulsory commitment, she has been working on further developing it's post 2012 approach and determining it's commitment. For example it has set a unilateral quantitative target for $\mathrm{CO}_{2}$ emissions from energy sector $(-7 \%$ from scenario level in 2020) as determined in it's 2009 National Climate Change Strategy report [2]. Both biofuels targets and greenhouse emission commitments will bring important implications in agriculture, industry and household sector. There has been increasing effort in energy production from biomass, but, unfortunately official statistics are not available to evaluate its contribution to energy supply and GHG emission reduction.

\section{Conclusion}

Turkey has no large oil and natural gas reserves and it's domestic energy supply is low relative to total demand. Hence Turkey is dependent on i mported energy sources that constitutes big burden on the economy. Turkey has potential for further growth in energy demand as a result of social and economic development. Growing energy consumption combined with the insufficient primary energy sources negatively effects not only the foreign trade balance and greenhouse emissions but also energy security. Moreover growing demand makes additional investments inevitable in energy sector. These issues constitute dilemma for energy policy in Turkey.

If the precautions cannot be taken in time, Turkey will be at the risk of energy deprivation and volatility of energy prices. Electricity energy demand also has been growing so it has pressure on other primary energy resources and also investment needs. Investments in electricity generation capacity have to be enhanced. Improvement in electricity market in terms of competition would have positive impact on increasing the domestic and foreign private funds in the sector. Much more exploiting hydro and other renewable resource such as wind, biomass, solar for electricity generation would contribute both in generating capacity and also energy security. Increasing the renewable energy usage and supporting the R\&D studies in renewable energy technologies would improve the energy independency and economic development. Geothermal energy is a promising energy source for the future. Turkey has to develop the usage of solar and wind energies because the potential for these energies is good. Ensuring the sufficient energy supply for economic development should be the government's main target. According to the recent research [24], Turkey has potential about $25 \%$ for the efficient energy usage. In this context, government should stimulate the efficient energy using in the country and prepare additional regulations for the Renewable Energy Strategies. Environmental concern has risen because of the high value GHG especially emitted from energy sector. Although there is a development in energy efficiency in Turkey, the efficiency of energy is not as important as in Europe. Although Turkey has no of ficial target for $\mathrm{CO}_{2}$ emissions, eventually she will have to prepare its plan. In this context, emission targets will bring important commitments on households and industries.

\section{References}

[1] Shaffer B., Turkey's Energy Policies in a Tight Global Energy Market, 2010, http://belfercenter.ksg.harvard.edu/files/insight turkey_shaffer_energy.pdf, acces date 9/10/2010.

[2] IEA, Energy Policies of IEA Countries: Turkey 2009 Review, OECD/IEA 2010, France, 2010. 
[3] Ozkivrak O., Electricity restructuring in Turkey, Energy Policy, 33(10), 2005, pp.13391350.

[4] Erdogdu E., Regulatory reform in Turkish energy industry: An analysis, Energy Policy, Vol.35, 2007, pp.984-993.

[5] TURKSTAT, Statistics, 2010, www.turkstat.gov.tr, acces date 1/11/2010.

[6] IMF, Country Information:Turkey, 2010, www.imf.org.tr, Access date 4/11/2010.

[7] MFA, Ministry of Foreign Affairs, The Republic of Turkey, Turkey's Energy Strategy, 2006, http://www.econturk.org/Turkisheconomy/energy turkey.pdf, Access date $4 / 12 / 2010$.

[8] Toklu E., Guney M.S., Isık M., Comakli O. and Kaygusuz K., Energy Production, consumption, policies and recent developments in Turkey, Renewable and Sustainable Energy Reviews, Vol.14, 2010, pp.1172-1186.

[9] SPO, State Planning Organization, Medium Term Program (2011-2013), Main Macroeconomic and Fiscal Targets, Turkey, 2010, www.dpt.gov.tr, acces date 24/1/2011.

[10]Balat M., Security of energy supply in Turkey:Challenges and solutions, Vol. 51, 2010, pp.1998-2011.

[11] Soyhan H.S., Sustainable energy production and consumption in Turkey:A Review, Renewable and Sustainable Energy Reviews, Vol.13, 2009, pp.1350-1360.

[12]MENR, Nuclear Energy, 2010a, http://www.enerji.gov.tr,, Access date 5/12/2010.

[13]MENR, Sectoral Energy Consumption 1970-2006, 2010b, http://www.enerji.gov.tr/ EKLENTI_VIEW/index.php/raporlar/raporVeriGir/4043/2, access date 2/12/2010.

[14]Demirbaş A., Turkey's Energy Overview beginning in the twenty-first century", Energy Conversion and Management, Vol.43, 2002, pp.1877-1887.

[15]TEIAS, Electricity Generation \& Transmission Statistics of Turkey 2009, 2010, http://www.teias.gov.tr/istatistik2009/index.htm, access date 24/11/2010.

[16] Turkyilmaz O., “Türkiye'nin Enerji Profili”, Türkiye'nin Enerji Gerçekleri ve Çıkış Yolları Sempozyumu, (The Energy Profile of Turkey, Syposium on Energy Realities of Turkey and Way Outs), 3 December 2010. MMO Antalya/Turkey, 2010.

[17]Kilic C.F. and Kaya D., Energy production, consumption, policies, and recent developments in Turkey, Renewable and Sustainable Energy Reviews, Vol.11, 2007, pp.1312-1320.

[18]Deloitte, Turkish Electricity Market: Developments and Expectations 2010 - 2011, 2010, https://www.deloitte.com/assets/DcomTurkey/Local\%20Assets/Documents/turkey-tr_er_ElektrikEPiyasasi2010_090710.pdf, Access date 10/5/2010.

[19]Ulutas B.H., "Determination of the appropriate energy policy for Turkey", Energy, Vol.30, 2005, pp.1146-1161.

[20]DTM, Türkiye'de Enerji Üretimi ve Tüketimi, (Undersecretariat of Prime Ministry for Foreign Trade, The Energy Production and Consumption in Turkey), 2010, http://www.dtm.gov.tr/dtmadmin/upload/EAD/KonjokturIzlemeDb/teut.doc, access date $15 / 12 / 2010$. 
[21]Demirbaş A., Energy Balance, Energy Sources, Energy Policy, Future Developments and Energy Investments in Turkey, Energy Conversion and Management, Vol.42, 2001, pp.1239-1258.

[22]Boluk G. And Koç A., Biofuels in World and Turkey: Production, policies, cost and impacts, ,Iktisat, Isletme ve Finans, 23(269), 2008, pp.25-50.

[23]EC, Communication from the Commission to the European Parliment, The council, The European Economic and Social Committee and the Committee and the Regions, Energy 2020 A strategy for competitive, sustainable and secure energy, 2010, www.europa.eu.int, Access date 10/10/2010.

[24]Keskin T., “Türkiye'nin Enerji Verimliliği İmkanları”, Türkiye’nin Enerji Gerçekleri ve Çıkış Yolları Sempozyumu, (The Energy Efficiency Possibilities of Turkey, Symposium on Energy Realities of $\mathrm{T}$ urkey and Way Outs), $3 \mathrm{D}$ ecember 2010. MMO Antalya/Turkey, 2010. 